\title{
THE IMPORTANCE OF MENTORING IN EMPLOYEE WORK ENGAGEMENT - BASED ON RESEARCH OF COMPANY EMPLOYEES IN POLAND
}

\author{
Małgorzata Baran*
}

\begin{abstract}
Background. The success of a company, in addition to today's very turbulent and demanding external environment, is influenced by internal organisational factors. In particular, a pivotal role in a company's success is undoubtedly played by human capital, where engagement at work manifests itself through employees with identified approaches, attitudes, views, and behaviours. Research indicates that mentoring can be an effective tool for supporting employees, because it influences not only development, in the broad sense, of the employees themselves, but also the development of the entire organisation. By affecting employees' attitudes and behaviour, it influences their commitment to work, which can contribute to the success of the whole organisation.
\end{abstract}

Research aims. The purpose of this article is to examine the relationship between employees' use of mentoring in the company and their engagement at work.

Methodology. A quantitative study was conducted on a non-probable sample of 1,010 employees of companies operating in Poland ${ }^{* *}$ who had participated in a mentoring programme in their company. Only employees who had completed a mentoring programme were selected for this study. Data collection was achieved through a questionnaire survey. The method used allowed the author to obtain aggregate and comparable data by using standardised questions. This research made use of Schaufeli's frequently employed concept of work engagement. The questionnaire used in this study was the Utrecht Work Engagement Scale.

Key findings. The findings demonstrate the importance of the mentoring process in shaping employee engagement in work. The involvement of employees in the mentoring process was found to affect their engagement. According to statistical analysis of the obtained results, the work engagement of employees is positively correlated with in-house mentoring programme participation.

Keywords: mentoring, work engagement, employees.

* Collegium Civitas. E-mail: malgorzata.baran@civitas.edu.pl

** The term "companies in Poland" used in this work refers to companies that are both registered in the Polish National Court Register and who conduct their business activities in Poland. 


\section{INTRODUCTION}

The success of a company, in addition to today's very turbulent and demanding external environment, is influenced by internal organisational factors. In particular, a pivotal role in a company's success is undoubtedly played by human capital, where engagement at work manifests itself through employees with specific emotions, attitudes, and behaviours (Juchnowicz, 2010a). Research indicates that mentoring is an effective tool for supporting employees. It influences not only development, in the broad sense, of the employees themselves, but also the development of the entire organisation. By affecting employees' attitudes, emotions, and behaviour, it influences their work engagement, thereby contributing to the success of the business (Harter et al., 2006). Engagement from the perspective of the organisation can manifest itself in a variety of forms: a commitment to the institution, the employer; a commitment to one's work and profession; and a commitment to the social environment in which the employees function (Juchnowicz, 2010b, pp. 57-58). For the purposes of this study, one form of employee engagement was analysed, namely, their commitment to work.

This article aims to identify the relationship between the employee's experience of in-house mentoring and their work engagement.

In order to do so, a quantitative study was conducted of a non-probability sample of 1,010 employees of companies operating in Poland, who participated in in-house mentoring programmes.

The article is divided into three parts. The first, a literature review, concerns the characteristics of mentoring in terms of how it engages employees in their work. The second presents the methodology of the empirical research, the characteristics of the research sample, and an overview of the statistical analysis. The third part is a discussion of the results of the research as well as conclusions that ensue.

\section{MENTORING AS A TOOL FOR EMPLOYER PROFESSIONAL SUPPORT}

Mentoring, in the broadest sense of the term, is a way to help individuals and organisations achieve business objectives based on the potential of the mentee to make use of the knowledge and experience 
of the mentor (Coaching Center, 2016). Mentoring is a purposefully implemented process meant to support the employees of an organisation (Baran, 2016).

According to many authors, mentoring is an effective tool for employee development (Kram, 1983; Clutterbuck, 2002; Ragins, 2002; Parsloe, 2000; Garvey \& Alred, 2001). Here it is worth clarifying the concept of a "mentoring process": it is a process launched intentionally within the organisational context (Garvey et al., 2009). Mentoring features all sectors and is designed to address a wide range of purposes (Hansford et al., 2002; Gravells, 2006; Megginson \& Stokes, 2004). It produces benefits for the whole organisation as well as for the mentor and mentee (Wilson \& Elman, 1990; Clutterbuck, 2002; Hansford \& Ehrich, 2006; Allen, 2007). By actively participating in the mentoring process, an employee can effectively meet their own goals as well as the goals of the organisation (Friday \& Friday, 2002; Irving et al., 2003; Higgins, 2000). Mentoring can be effective at every stage of an employee's career (Fajana \& Gbajumo-Sheriff, 2011). It also creates added value for the company: for example, the development of organisational competencies and an improved atmosphere encourages employees to become more engaged in their work, thereby increasing levels of motivation) (Parsloe, 2000; Klasen \& Clutterbuck, 2002; Baran, 2014).

The literature review allowed the author to describe the effects of an employee participating in the mentoring process in terms of their work and professional career. Studies on the so-called "career-related outcomes" can be found in the work of Eby et al., 2006 (Ragins and Cotton, 1999; Ragins and McFarlin, 1990; Allen \& Eby, 2004, e.g. Collins and Scott, 1978; Roche, 1979; Zey, 1988). Mentoring has been shown to improve the productivity of mentees, speed up their career advancement, often raise their salaries, encourage them to work more, and boost satisfaction with their work (Allen \& Eby, 2004; Chao, 1997; Dreher \& Ash, 1990; Fagenson, 1989). Among the analysed mentoring outcomes, two categories can be distinguished:

- $\quad$ Extrinsic career success (Johnson \& Scandura, 1994; Allen \& Eby, 2004).

This includes better career advancement (Koberg et al., 1994), higher pay increases (e.g.: Dreher \& Ash, 1990; Scandura, 1992); an above average level of earnings (Dreher \& Ash, 1990; Turban \& Dougherty, 1994).

- Intrinsic career success 
The most common outcome of this category is the professional satisfaction of mentees, which includes increased satisfaction with professional life (Fagenson, 1989; Scandura, 1992), increased job satisfaction, decrease in job burnout, and increased work engagement (Higgins, 2000).

\section{THE ESSENCE OF WORK ENGAGEMENT}

The scholarly literature on the subject shows that the term "work engagement" is understood in a variety of ways. The literature review indicates that an unequivocal definition of this term does not exist.

A.M. Saks (2006, pp. 601-602) identifies work engagement as effort invested in work, which, rather like the idea of dedication, expresses the intellectual and emotional commitment to an organisation. In turn, Britt (1999, pp. 696-706) believes that work engagement is an attachment to work and a sense of responsibility towards work because an engaged worker feels a personal responsibility for the outcomes of the tasks performed. Work engagement may also be related to the performance of daily duties. Gierveld and Bakker (2005) found that engaged employees had a greater impact on their work, and could perform additional tasks beyond their core responsibilities with their superiors even willing to assign them difficult tasks (Smythe, 2009, p. 234; Gierveld \& Bakker, 2005). Of course, the intensity of engagement may vary. It can manifest itself in the constant effort to work conscientiously, or it can surpass such effort by undertaking activities that go above and beyond planned goals and targets (Bakker \& Bal, 2010, pp. 189-206; Meyer \& Smith, 2000, pp. 319-332).

On the other hand, Robinson, Perryman, and Hayday (2004) note that engagement can be viewed as a positive attitude towards the company in which one works. The key then is the mutual interaction between the employee and his/her company, a relationship based on transparent principles, a single business value system and the joint pursuit of goals. Such work engagement from the employee is also perceived as a state in which the employee functions optimally in the organisation (Schaufeli \& Van Rhenen, 2006). Increasing job demands or an imbalance between work and personal life can reduce employee engagement, sometimes even leading to burnout (Schaufeli 
et al., 2008). Therefore, work engagement is often thought of as the opposite of burnout (Maslach et al., 2001, pp. 397-422).

Engagement is equally often understood as a positive, fulfilling, work-related state of mind, that according to Schaufeli's conceptualisation consists of three factors: the employee's feelings of vigour while doing work, their dedication to work, and their absorption in work. Vigour is understood as the experience of high energy levels and psychological endurance during work as well as resistance to diverse distractors. It also incorporates a desire to work even in the face of emerging adversities and difficulties. Dedication to work means doing it enthusiastically, experiencing a sense of its importance, and feeling pride for the very opportunity of being able to do it. As for absorption in work, this refers to feelings of full concentration and immersion, which may be accompanied by the perception of time passing unnaturally quickly (Schaufeli \& Bakker, 2003, pp. 4-5).

Shirom (2011, pp. 50-64), by contrast, in defining engagement, speaks of vigour manifested by a feeling of physical strength, emotional energy, and cognitive liveliness during work. Russel (2003, pp. 145-172) indicates a range of positive emotions accompanying work engagement, i.e. excitement, enthusiasm, satisfaction, a feeling of being energised, pleasure, and happiness.

\section{THE IMPACT OF MENTORING ON WORK ENGAGEMENT}

Mentoring is referred to as the transfer of knowledge, attitudes, and values such as loyalty, engagement, quality, and respect (Clutterbuck, 2002; Higgins, 2000). Loyal, motivated, and engaged employees influence the development of the organisation by building positive relations not only inside the organisation, but also with the outside environment, thereby contributing to the organisation's image. Managers often wonder how to increase their employees' satisfaction, work engagement, and loyalty. The answer to these questions may well comprise mentoring. Since managers are aware that a satisfied and engaged employee contributes to the success of the organisation, they recognise that a mentor not only works on an employee's overall development, but above all on their attitude to work-related tasks. Furthermore, it has been proven that an engaged employee may exert influence on other 
less engaged colleagues and thus impact the quality of their work (Van Knippenberg, 2000). It turned out that people engaged in their work are seen as a source of inspiration and positivity, particularly in situations where jobs produce a lot of employee frustration. A study by Schaufeli and Bakker (2004) demonstrated significant and positive relationships between engagement and productivity, and between creativity and leadership skills. They showed that the people studied (engaged) exhibited transformational leadership characteristics: that is to say, they inspire, excite, and influence the development of their colleagues.

Whatever the situation, mentors help mentees take key decisions, and offer advice on both the mentee's personal development and on managing their career. In most organisations, overall performance is the result of the combined efforts of individual employees. Given colleagues can positively influence each other and the engagement of even one person is of the utmost importance to the team. As a result, such a person's impact on those immediately around them has a positive effect on the efficiency of the entire team (Westman, 2001; Sy et al., 2005; Barsade, 2002).

In addition, studies have shown that the level of employee engagement in work is correlated with their rate of efficiency (Bakker $\&$ Bal, 2010) and that engagement is one of the most important factors responsible for organisational success (Harter et al., 2006). Furthermore, there are studies that show that employee engagement positively correlates with investing more effort in work. Known as "extra-role performance", such effort involves carrying out tasks that go beyond the responsibilities ordinarily assigned to the job (Halbesleben $\&$ Wheeler, 2008). It has also been shown that engagement in work is linked to the company's functional efficiency (Harter et al., 2002; Salanova et al., 2005; Kruse, 2012).

The mentoring process aimed at increasing work engagement may therefore contribute to an increase in effort when employees undertake assigned tasks, increase company performance and efficiency, and underscore the values of the organisation, which subsequently contribute to the achievement of success and competitiveness in the market. Furthermore, engagement-oriented mentoring leads to an increase in employee well-being, triggers positive emotions, reinforces self-esteem, and boosts optimism. Mentoring affords the opportunity to be inspired for the employees. What is crucial in this process is the 
relationship between mentor and mentee. If it is based on a partnership, understood as a friendly relationship incorporating respect and trust, then the process of mentoring can succeed and increase work engagement. Research by Hakanen, Bakker, and Schaufeli (2006) revealed that work engagement is positively correlated to self-esteem. Positive emotions related to engagement not only make people feel good at any given moment, but also help them view their future positively. Such engaged people exude high energy, have a sense of self-efficiency, have optimistic attitudes towards their work, and boast high self-esteem (Schaufeli et al., 2002). Studies also show that engaged employees often experience positive emotions (Schaufeli \& Van Rhenen, 2006), which can impact their performance.

Happy people are more likely to be open and helpful to others, as well as being confident and full of optimism (Cropanzano \& Wright, 2001). Engaged employees are better able to motivate themselves to do their work, which in the future may result in even greater engagement and improved performance at work (Schaufeli et al., 2008; Luthans et al., 2008).

Mentoring based on partnership may also help to create a positive atmosphere in the organisation. Through a mentoring relationship, the mentee is guaranteed the opportunity to exchange thoughts on professional topics, and the freedom to search for solutions to problems encountered in the workplace. When risky or problematic situations arise, or if quick changes are needed, engaged employees can more effectively motivate themselves and act under pressure compared to employees with lower levels of engagement (George, 2010). Resolving problematic and critical situations is undeniably more effective when a mentoring process is put into practise in the organisation.

The implementation of mentoring programmes, therefore, is of the utmost importance with respect to the functioning of the entire organisation, as well as to individual members. A mentoring programme fosters staff attitudes conducive to achieving organisational success, increases loyalty of employees, and acts as an inspiration for employee professional development. Mentoring is used as a tool to encourage engagement in work, which increases the employee's sense of satisfaction with their own professional achievements. Engaged employees are more willing to get the job done, are devoted to it, work more efficiently, and accomplish their professional goals faster (Luthans et al., 2008). 
In conclusion, mentoring, as demonstrated by this literature review, can translate into work engagement and, consequently, into an employee's professional success. The question thus arises as to whether there is a direct relationship between the employee's participations in a mentoring programme and their engagement in work.

\section{METHODOLOGY}

\section{Methodology of the study}

In the first quarter of 2017 , a quantitative study was conducted on a non-probable sample (as described by Babbie, 2003; Frankfort-Nachmias \& Nachmias, 2001) of 1,010 employees from companies operating in Poland* who had participated in a mentoring programme in their company. The criterion of the employee's participation in the study was the completion of the mentoring process in the company. Data collection was achieved through a questionnaire survey. The method used allowed the author to obtain aggregate and comparable data by using standardised questions (Babbie, 2003).

This research made use of Schaufeli's frequently employed concept of work engagement (Schaufeli et al., 2002). The questionnaire used in this study was the Utrecht Work Engagement Scale (UWES) (Schaufeli et al., 2006). The questionnaire consists of 9 statements related to the respondent's work (see Table 1 ), with replies ranging from 0 to 6 ( 0 - never, 6 - always), subdivided into 3 sections: vigour, absorption, and dedication.

\section{Sample characteristics}

1,010 company employees took part in the survey including 655 women $(64.9 \%)$ and 355 men (35.1\%). 65.0\% of the respondents were aged $20-29,21.7 \%$ were $30-39,10.7 \%$ were $40-49$, and $2.3 \%$ were $50-60$. Three of the respondents $(0.3 \%)$ were over 60 years old. 514 respondents (50.9\%) had completed higher education, while 496

* The term "companies in Poland" used in this work refers to companies that are both registered in the Polish National Court Register and who conduct their business activities in Poland. 
(49.1\%) had completed secondary education. 199 people (19.7\%) worked in managerial positions, 308 (30.5\%) were specialists, 93 (9.2\%) were manual workers, 288 (28.5\%) were white-collar workers, $83(8.2 \%)$ were sales representatives and 39 (3.9\%) worked in other positions. 211 people (20.9\%) had been employed for less than a year. 391 people (38.7\%) had been employed for a period of $1-3$ years, 225 (22.3\%) for 3-5 years, 96 (9.5\%) for 5-10 years, and 87 (8.6\%) for over 10 years. As for the respondents' industrial sector, 40.2\% worked in service companies, $9.6 \%$ in manufacturing companies, $21.9 \%$ in trading companies, 167 (16.5\%) in mixed companies, and $119(11.8 \%)$ in other companies. 664 people (65.7\%) worked in companies with Polish capital, 224 (22.2\%) in companies with foreign capital, and 122 (12.1\%) in companies with mixed capital. 141 people (14.0\%) worked in micro-enterprises (with up to 9 employees), 263 (26.0\%) in small companies (with 10-49 employees), 232 (23.0\%) in medium companies (with 50-249 employees), and 374 (37.0\%) in large companies (with at least 250 employees).

\section{Overview of the statistical analysis}

First a principal component analysis was conducted on the results obtained from mentoring experience questions and on those obtained from work engagement questions. This analysis allowed the author to determine whether the use of mentoring and work engagement could be analysed as a single relationship or whether it was necessary to differentiate subcategories in order to analyse different dimensions of mentoring and/or employee work engagement. The decision about the number of extracted dimensions is based on independent values for consecutive (subsequent) components. In order to examine whether the sample size was suitable for undertaking a factor analysis, the Kaiser-Meyer-Olkin (KMO) measure of sampling adequacy was calculated. Also the correlation matrix determinants were calculated to determine if some of the questions about mentoring or some of the questions about work engagement do not correlate with each other much more strongly than the remaining questions. The reliability of measurements of work engagement and mentoring use was verified by calculating Cronbach's alpha estimate of reliability.

Next the relationship between mentoring use and work engagement was analysed by calculating the Spearman's rank correlation coefficient. 
The relationship between mentoring use and general work engagement was analysed by working out the Pearson correlation coefficient.

An analysis was also conducted on the relationship between mentoring use and gender, age, education, position, type of business, the origin of company capital, and the number of employees in the company. The analysis was conducted using one-way analysis of variance followed by the Gabriel post hoc test. The Gabriel test results revealed which of the compared groups of respondents differed from the rest in a statistically significant manner.

\section{MENTORING USE AND WORK ENGAGEMENT - A REVIEW OF RESEARCH RESULTS}

The first stage of the analysis involved verification of the applied research tools. The results from questions about employees' experience of mentoring were put through a principal component analysis. Since only the first component had an eigenvalue greater than 1 (see Figure 1), this particular dimension of mentoring - accounting for $53.78 \%$ of variation - was thus selected for further analyses.

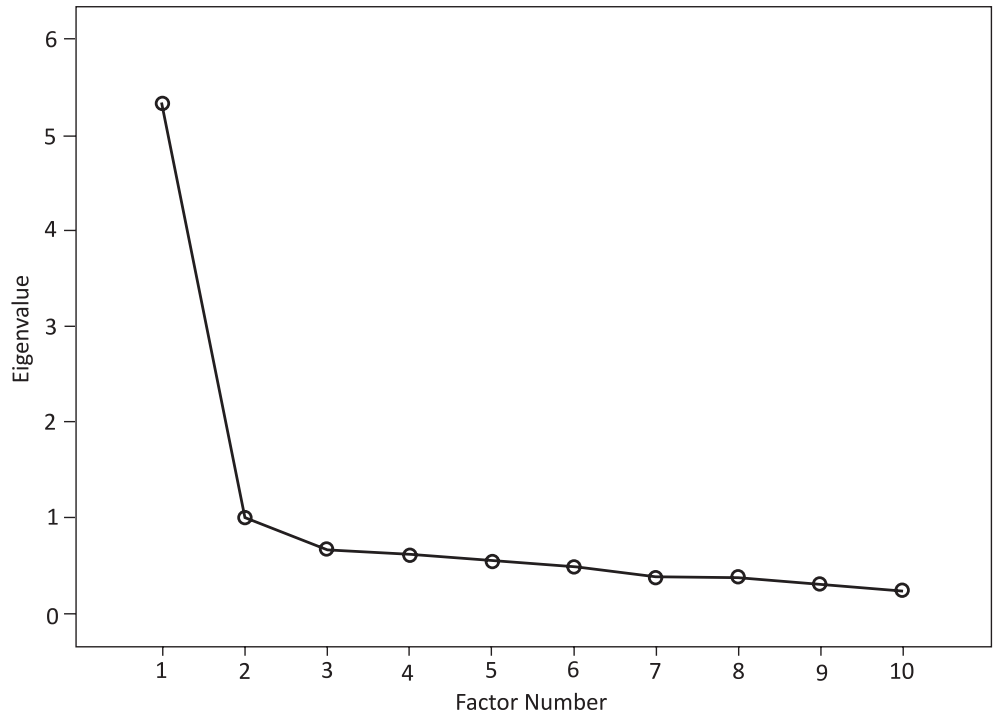

Figure 1. Scree plot - experience of mentoring

Source: diagram based on the author's research. 
A similar analysis was conducted on the results from questions about work engagement. Here as well, only the first component had an eigenvalue greater than 1 (see Figure 2). Thus one dimension of work engagement, accounting for $61.01 \%$ variation, was selected.

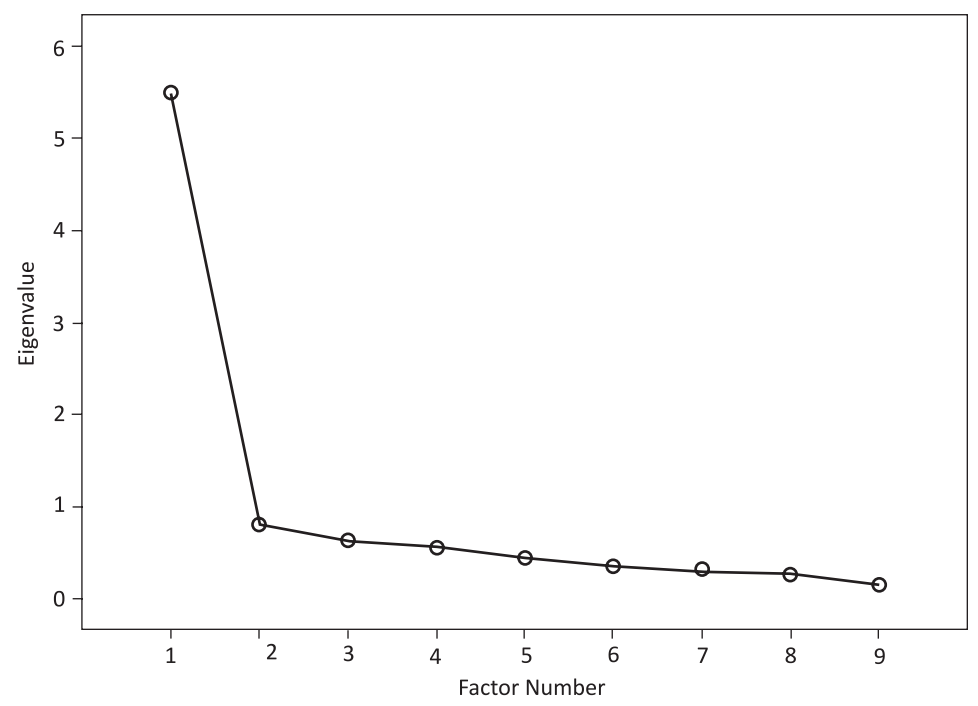

Figure 2. Scree plot - satisfaction from work

Source: diagram based on the author's research.

Then the research sample size was verified to see if it was suitable. The KMO measure of sampling adequacy was calculated in relation to the experience of mentoring. This came to 0.92 , compared to 0.91 for work engagement. In both cases the index exceeded 0.5, the threshold above which the size of the sample is considered to be sufficient.

The correlation matrix determinant in the analysis of mentoring was 0.007 and in the analysis of work engagement it was 0.003 , with both cases exceeding the required threshold of 0.00001 . The result shows that the questions used in the research tool correlate with each other with similar coefficients. Then, to confirm the accuracy of the tools and the previous results, Cronbach's alpha test was used. At 0.90, the accuracy of the measurement of the overall level of mentoring use, as measured by Cronbach's alpha test, was high. The accuracy of the measurement of the overall level of work engagement was also high and came to 0.92 .

An in-depth statistical analysis sought to discover if there is a correlation between mentoring use and the overall level of work 
engagement and the relationship between mentoring and the results from separate questions and the scales studying work engagement. Table 1 shows the Spearman's rank correlation coefficient $\rho$ between mentoring use and the results of individual questions that measure the level of work engagement.

Table 1. Spearman's rank correlation coefficient $\rho$ between mentoring use and the results of individual questions that measure the level of work engagement

\begin{tabular}{|l|c|}
\hline \multicolumn{1}{|c|}{ Work Engagement } & Use of Mentoring \\
\hline Vigour & $0.344^{* * *}$ \\
\hline At work I feel that I am bursting with energy & $0.317^{* * *}$ \\
\hline At work I feel strong and full of energy & $0.330^{* * *}$ \\
\hline When I get up in the morning, I feel like going to work & $0.275^{* * *}$ \\
\hline Dedication & $0.308^{* * *}$ \\
\hline I am dedicated to my work & $0.228^{* * *}$ \\
\hline My work inspires me & $0.262^{* * *}$ \\
\hline I am proud of the work I am doing & $0.310^{* * *}$ \\
\hline Absorption in work & $0.287^{* * *}$ \\
\hline I feel happy when I work hard & $0.230^{* * *}$ \\
\hline I am preoccupied with my work & $0.257^{* * *}$ \\
\hline I lose track of time when I work & $0.212^{* * *}$ \\
\hline
\end{tabular}

$* * * p<0.01$

Source: table based on the author's research.

Significant positive correlations were obtained between mentoring use and all aspects of work engagement. This means that employees who participate in mentoring programmes feel engaged in the work. Mentoring also positively correlates with individual questions as well as the three aforementioned engagement scales (vigour, dedication, and absorption).

The next more advanced statistical analysis calculated the correlation between mentoring use and the overall level of engagement in work. Also, the value of the Pearson correlation coefficient $r$ revealed a significant positive correlation between the experience of mentoring use and the overall level of work engagement: $\mathrm{r}(1008)=0.361, \mathrm{p}<0.001$. 
The result shows that people involved in the mentoring process exhibit greater overall engagement in work, and as such, positive correlation is not limited to particular questions or dimensions.

\section{Relationships between mentoring use, work engagement, and the age and position of the employee}

The aim of the next in-depth statistical analysis was to examine whether there is a statistically significant relationship between mentoring use, work engagement, and the age of the employee. Table 2 shows Spearman's rank correlation coefficient $\rho$ between mentoring use and the results of individual questions that measure the level of work engagement in three age groups.

Table 2. Spearman's rank correlation coefficient $\rho$ between mentoring use and the results of individual questions that measure the level of work engagement in three age groups.

\begin{tabular}{|l|c|c|c|}
\hline & \multicolumn{3}{|c|}{$\begin{array}{c}\text { Use of Mentoring } \\
\text { (Mentoring experience) }\end{array}$} \\
\hline Work Engagement & $\begin{array}{c}20-29 \\
\text { years of age }\end{array}$ & $\begin{array}{c}30-39 \text { years } \\
\text { of age }\end{array}$ & $\geq 40$ \\
\hline Vigour & $0.401^{* *}$ & $0.322^{* *}$ & $0.231^{* *}$ \\
\hline At work I feel that I am bursting with energy & $0.369^{* *}$ & $0.311^{* *}$ & 0.134 \\
\hline At work I feel strong and full of energy & $0.360^{* *}$ & $0.339^{* *}$ & $0.213^{* *}$ \\
\hline $\begin{array}{l}\text { When I get up in the morning, I feel like going } \\
\text { to work }\end{array}$ & $0.344^{* *}$ & $0.250^{* *}$ & $0.236^{* *}$ \\
\hline Dedication & $0.393^{* *}$ & $0.298^{* *}$ & 0.113 \\
\hline I am dedicated to my work & $0.295^{* *}$ & $0.221^{* *}$ & 0.047 \\
\hline My work inspires me & $0.335^{* *}$ & $0.267^{* *}$ & 0.085 \\
\hline I am proud of the work I am doing & $0.384^{* *}$ & $0.262^{* *}$ & $0.194^{* *}$ \\
\hline Absorption in work & $0.372^{* *}$ & $0.245^{* *}$ & 0.131 \\
\hline I feel happy when I work hard & $0.307^{* * *}$ & $0.176^{* *}$ & 0.097 \\
\hline I am preoccupied with my work & $0.331^{* *}$ & $0.209^{* *}$ & 0.119 \\
\hline I lose track of time when I work & $0.269^{* * *}$ & $0.185^{* *}$ & 0.102 \\
\hline
\end{tabular}

$* \mathrm{p}<0.05 ; * * \mathrm{p}<0.01 ; * * * \mathrm{p}<0.01$

Source: Table based on results from the author's research. 
Correlations for the oldest age group were the least statistically significant, indicating that the mentoring experience translated to fewer areas of work engagement (i.e. vigour and absorption) for this particular cohort.

Therefore mentoring appears to be less important for the over forties when it comes to increasing work engagement.

Pearson's correlation coefficient $r$ showed that there was a significant positive correlation between the experience of mentoring use and the overall level of work engagement. This correlation was statistically significant for the 20-29 age group, where $\mathrm{r}(653)=0.439$ and $\mathrm{p}<0.001$; and as well as for the other cohorts, $r(218)=0.366$ and $p<0.001$ for the $30-39$ age group, and $r(132)=0.223$ and $p<0.05$ for the $40+$ age group.

In the next in-depth statistical analysis, the relationship between mentoring use, work engagement, and job position was examined. Table 3 shows Spearman's correlation coefficients $\rho$ between mentoring use and results from individual work engagement components in three job cohorts: managers, specialists, and manual/clerical workers.

Table 3. Spearman's correlation coefficients $\rho$ between mentoring use and results from individual work engagement components in three job cohorts: managers, specialists, and manual/clerical workers.

\begin{tabular}{|l|c|c|c|}
\hline & \multicolumn{3}{c|}{ Position } \\
\hline \multicolumn{1}{|c|}{ Work Engagement } & Managers & Specialists & Manual/clerical \\
\hline Vigour & $0.224^{* *}$ & $0.332^{* *}$ & $0.391^{* *}$ \\
\hline At work I feel that I am bursting with energy & $0.225^{* *}$ & $0.268^{* *}$ & $0.375^{* *}$ \\
\hline At work I feel strong and full of energy & $0.260^{* *}$ & $0.288^{* *}$ & $0.374^{* *}$ \\
\hline $\begin{array}{l}\text { When I get up in the morning, I feel like going } \\
\text { to work }\end{array}$ & $0.174^{* *}$ & $0.332^{* *}$ & $0.278^{* *}$ \\
\hline Dedication & $0.139^{* *}$ & $0.319^{* *}$ & $0.372^{* *}$ \\
\hline I am dedicated to my work & 0.073 & $0.252^{* *}$ & $0.267^{* *}$ \\
\hline My work inspires me & 0.134 & $0.265^{* *}$ & $0.312^{* *}$ \\
\hline I am proud of the work I am doing & $0.149^{* *}$ & $0.311^{* *}$ & $0.373^{* *}$ \\
\hline Absorption & $0.161^{* *}$ & $0.305^{* *}$ & $0.323^{* *}$ \\
\hline I feel happy when I work hard & 0.125 & $0.254^{* *}$ & $0.250^{* *}$ \\
\hline I am preoccupied with my work & 0.129 & $0.292^{* *}$ & $0.285^{* *}$ \\
\hline I lose track of time when I work & 0.111 & $0.180^{* *}$ & $0.266^{* *}$ \\
\hline
\end{tabular}

$* \mathrm{p}<0.05 ; * * \mathrm{p}<0.01 ; * * * \mathrm{p}<0.01$

Source: Table based on the author's research. 
However, Pearson's correlation coefficient $r$ showed that there was a significant positive correlation between mentoring use and the overall level of work engagement. This correlation was statistically significant for all three job cohorts: for managers $\mathrm{r}(197)=0.198$ and $\mathrm{p}<0.01$; for specialists $\mathrm{r}(305)=0.378$ and $\mathrm{p}<0.001$; and for manual/clerical workers $r(501)=0.400$ and $p<0.001$. Thus it is clear that managers, specialists, and manual/clerical workers participating in the mentoring process are all generally engaged in work. This analysis, though, did not address the three separate work engagement components (vigour, dedication, and absorption).

\section{Mentoring with respect to gender, age, and education}

The aim of the next in-depth statistical analysis - a one-way analysis of variance - was to identify the relationship between mentoring use and gender, age, and education.

There was no statistically significant difference between women and men with respect to participation in the mentoring process, where $\mathrm{F}(1,1008)=3.19$ and $\mathrm{p}>0.05$; nor was there any between people with secondary education and people with higher education, where $\mathrm{F}(1,1008)$ $=1.89$ and $\mathrm{p}>0.05$. This means that the decision to partake in the mentoring process is not affected by the employee's gender or education.

However, a statistically significant relationship was found to exist between mentoring use and the age of the subject, where $\mathrm{F}(2,1007)=$ 10.98 and $p<0.001$. It can be ascertained from the results of the study that on average the use of mentoring received, at most, 30 points. The Gabriel post hoc test found that there were statistically significant differences between people aged 20-29 and those aged 30-39 $(\mathrm{t}=2.78$ and $\mathrm{p}<0.05$ ), as well as between people aged 20-29 and those aged 40 or over $(t=4.26, p<0.001)$. The average level of mentoring use in the youngest age group was 25.01 with a standard deviation of 6.23. This was higher than the average values obtained in both the 30-39 age group (23.61 with a standard deviation of 7.01) and the 40 or over age group (22.41 with a standard deviation of 6.35) - see Figure 3.

Since the average value of the level of mentoring use in the youngest cohort was high and close to the 30 point scale maximum, one can deduce that the youngest people had participated more in the mentoring process. One can conclude, therefore, that the level of mentoring use was highest in the youngest age group. 


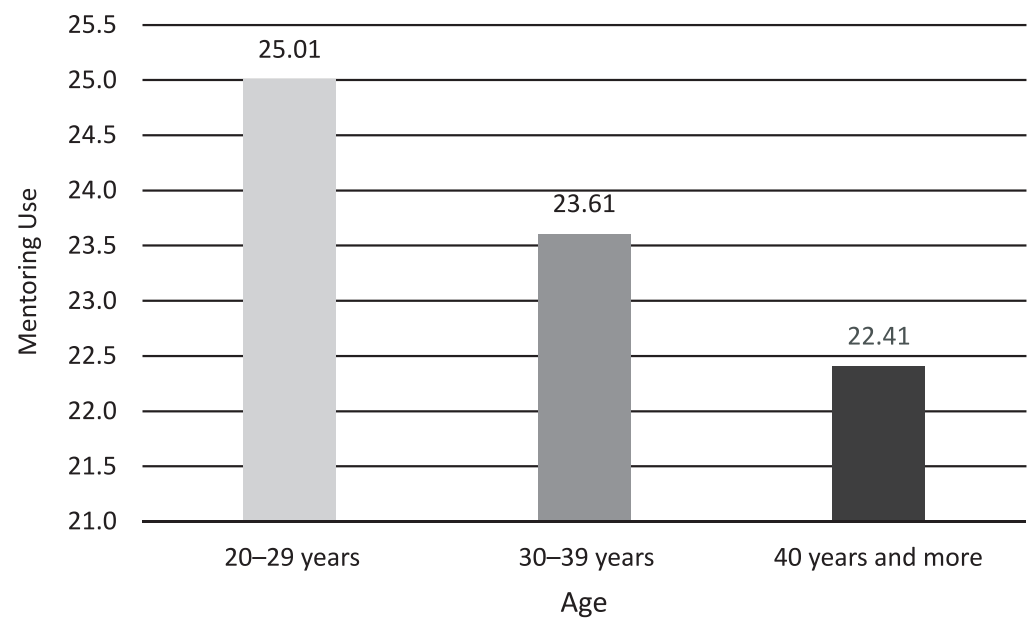

Figure 3. Average levels of mentoring use in different age groups Source: Diagram based on the author's research.

On the other hand, there was no statistically significant relationship between mentoring use and the duration of employment, where $\mathrm{F}(2,1007)=2.26$ and $\mathrm{p}>0.05$; thus the decision to participate in the mentoring process appears to be taken regardless of employment duration.

\section{The use of mentoring and the employee's job position}

A statistically significant relationship was found to exist between mentoring use and the subject's position in the company, where $\mathrm{F}(2,1007)=3.30$ and $\mathrm{p}<0.05$. The Gabriel post hoc test revealed that the average value of results on the mentoring use scale (max. average 30 points) was higher for managers than for specialists: the former amounted to 25.41 with a standard deviation of 6.49 and the latter came to 24.00 with a standard deviation of 6.24 , where $t=2.37$ and $\mathrm{p}<0.05$ (see Figure 4).

Since the average value of the level of mentoring use in the managerial cohort was high and close to the 30 point scale maximum, one can deduce that managers had participated most frequently in the mentoring process. 


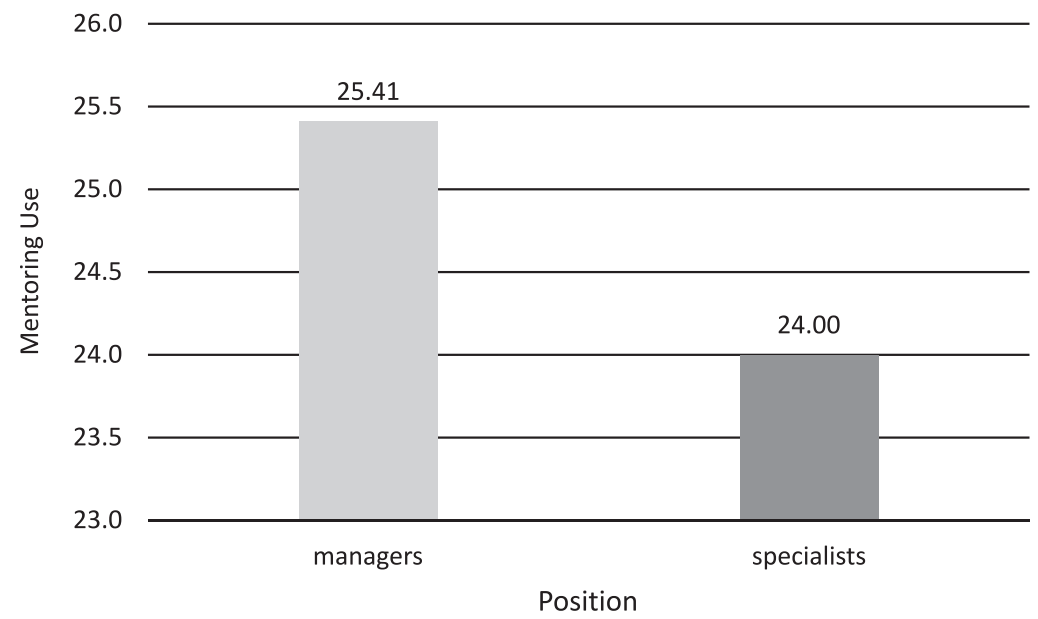

Figure 4. Average level of mentoring use for managers and specialists Source: Diagram based on the author's research.

\section{The use of mentoring and the type of business, origin of capital, and business size}

A statistically significant relationship was found to exist between mentoring use and the origin of the company's capital, where $\mathrm{F}(2,1007)$ $=5.11$ and $\mathrm{p}<0.01$. The Gabriel post hoc test revealed that the average value of results on the mentoring use scale (max. average 30 points) was lower for employees in Polish companies than for employees in companies with foreign capital: the former amounted to 23.89 with a standard deviation of 6.45 and the latter came to 25.35 with a standard deviation of 6.33 , where $t=2.92$ and $p<0.01$.

Since the average value of the level of mentoring use for employees in companies with foreign capital was high and close to the 30 point scale maximum, one can deduce that these employees had participated most frequently in the mentoring process.

One can therefore conclude that the average level of mentoring use was lowest for employees in Polish companies in contrast to those in companies with foreign capital.

As for the industrial sector and company size, no statistically significant relationships were established either between mentoring use and the company's field of activity, where $\mathrm{F}(4.1005)=0.37$ and $p>0.05$, or between mentoring use and the number of employees, where $\mathrm{F}(3.1006)=1.77$ and $\mathrm{p}>0.05$. This means that the level of 
mentoring use did not exhibit a statistically significant correlation with either the company's field of activity or with its number of employees.

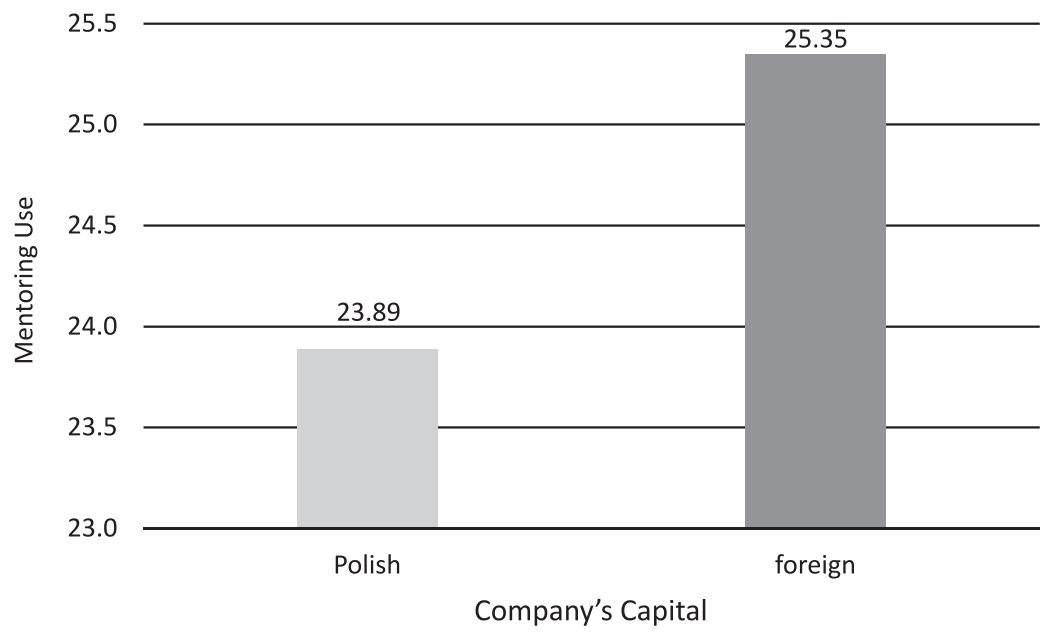

Figure 5. Average level of mentoring use for employees in Polish companies and for employees in companies with foreign capital

Source: Diagram based on the author's research.

\section{CONCLUSIONS}

The involvement of employees in the mentoring process was found to affect their engagement in work. This means that employees who participate in mentoring programmes feel engaged in the work. Mentoring also positively correlates with each aspect of work engagement (vigour, dedication, and absorption). According to the statistical analysis of the obtained results, the work engagement of employees is positively correlated with in-house mentoring programme participation. The value of the Pearson correlation coefficient $r$ revealed a significant positive correlation between the experience of mentoring use and the overall level of work engagement. That result shows that people involved in the mentoring process exhibit greater overall engagement in work.

On the basis of the study's results, one can also make the following specific conclusions:

1. Participation in the mentoring process is associated with greater work engagement; 
2. Mentoring impacts work engagement less for the over forties;

3. Mentoring impacts work engagement less for managers;

4. Participation in the mentoring process was the highest for the youngest cohort;

5. Participation in the mentoring process was the highest for those in managerial positions;

6. Participation in the mentoring process was lower for those employed in Polish companies compared to those employed in companies with foreign capital;

7. Participation in the mentoring process did not exhibit a statistically significant correlation with the employee's gender, how long they were employed, the field of activity of their company, or the size of their company.

The findings demonstrate the importance of the mentoring process in shaping employee engagement in work. Data from this study can be used to support future research on the effects of mentoring programs from the employees' perspective.

\section{REFERENCES}

Allen, T.D. (2007). Mentoring relationships from the perspective of the mentor. In: B.R. Ragins, K.E. Kram (eds.), The Handbook of Mentoring at Work: Theory, Research, and Practice. Thousand Oaks, CA: Sage, 123-147.

Allen, T.D. \& Eby, L.T. (2004). Factors related to mentor reports of mentoring functions provided: Gender and relational characteristics. Sex Roles, 50, $129-139$,

Babbie, E. (2003). Badania spoteczne w praktyce. Warszawa: Wydawnictwo Naukowe PWN, 205, 268-269.

Bakker, A.B., Bal, M.P. (2010). Weekly work engagement and performance: A study among starting teachers. Journal of Occupational and Organizational Psychology, 83(1), 189-206.

Baran, M. (2014). Mutual mentoring as a tool for managing employees of different generations in the enterprise. Journal of Positive Management, 5(2), 20-29.

Baran, M. (2016). Model of organizational rediness to implement mentoring. In: Proceedings of the $8^{\text {th }}$ International Joint Conference on Knowledge Engineering and Knowledge Management. Volume 3: KMIS, 208-214.

Barsade, S. (2002). The ripple effect: emotional contagion and its influence on group behavior. Administrative Science Quarterly, 47, 644-677. 
Britt, T.W. (1999). Engaging the self in the field: Testing the triangle model of responsibility. Personality and Social Psychology Bulletin, 25.

Bugdol, M. (2006). Wartości organizacyjne. Kraków: Wydawnictwo Uniwersytetu Jagiellońskiego.

Chao, G.T. (1997). Mentoring phases and outcomes. Journal of Vocational Behavior, $51,15-28$.

Clutterbuck, D. (2002). Każdy potrzebuje mentora. Jak kierować talentami. Warszawa: Petit.

Coaching Center (2016). Mentoring - podstawowe informacje. http://www.coachingcenter.pl.

Collins, E.G. \& Scott, P. (1978). Everyone who makes it has a mentor. Harvard Business Review, 56(4), 89-101.

Cropanzano, R. \& Wright, T.A. (2001). When a 'happy' worker is really a 'productive' worker: a review and further refinement of the happy-productive worker thesis. Consulting Psychology Journal: Practice and Research, 53, 182-199.

Dreher, G.F. \& Ash, R.A. (1990). A comparative study of mentoring among men and women in managerial, professional, and technical positions. Journal of Applied Psychology, 75, 525-535.

Eby, L.T., Durley, J.R., Evans, S.C. \& Ragins, B.R (2006). The relationship between short-term mentoring benefits and long-term mentor outcomes. Journal of Vocational Behavior, 69, 424-444.

Fagenson, E.A. (1989). The mentor advantage: Perceived career/job experiences of proteges vs. non-proteges. Journal of Organizational Behavior, 10, 309-320.

Fajana, S. \& Gbajumo-Sheriff, M. (2011). Mentoring: An human resource tool for achieving organisational effectiveness. In: A.A. Olowu (ed.), Mentoring: A Key Issue in Human Resource Management. Nigeria: The Ife Centre for Psychological Studies, 420-432.

Frankfort-Nachmias Ch. \& Nachmias D. (2001). Metody badawcze w naukach społecznych. Poznań: Zysk i S-ka, 199.

Fredrickson, B.L. \& Joiner, T. (2002). Positive emotions trigger upward spirals toward emotional well-being. Psychological Science, 13, 172-175.

Friday, E. \& Friday, S.S. (2002). Formal mentoring: Is there a strategic fit? Management Decision, 40(2), 152-157.

Garvey, B. \& Alred, G. (2001). Mentoring and the tolerance of complexity. Futures, $33,519-530$.

Garvey, B., Stokes, P. \& Megginson, D. (2009). Coaching and Mentoring Theory and Practice. London: Sage.

George, J.M. (2010). More engagement is not necessarily better: The benefits of fluctuating levels of engagement. In: S. Albrecht (ed.), The Handbook 
of Employee Engagement: Perspectives, Issues, Research, and Practice. Cheltenham: Edward Elgar, 253-263.

Gierveld, J.H. \& Bakker, A.B. (2005). De invloed van de secretaresse (The Influence of the Secretary). Diemen: Manpower.

Gravells. J. (2006). Case study 13: Mentoring owners of micro businesses in Nottingham. In: D. Megginson, D. Clutterbuck, B. Garvey, P. Stokes \& R. Garrett-Harris (eds.), Mentoring in Action. London: Kogan Page, 142-149.

Hakanen, J., Bakker, A.B. \& Schaufeli, W.B. (2006). Burnout and work engagement among teachers. Journal of School Psychology, 43, 495-513.

Halbesleben, J.R.B. \& Wheeler, A.R. (2008). The relative roles of engagement and embeddedness in predicting job performance and intention to leave. Work and Stress, 22, 242-256.

Hansford, B. \& Ehrich, L.C. (2006). The principalship: How significant is mentoring? Journal of Educational Administration, 44(1), 36-52.

Hansford, B., Tennent, L. \& Ehrich, L. (2002). Business mentoring: help or hindance? Mentoring and Tutoring, 10(2), 101-115.

Harter, J.K., Schmidt, F.L., Killham, E.A. \& Asplund, J.W. (2006). Q12 Meta-Analysis. Omaha: Gallup.

Harter, J.K., Schmidt, F.L. \& Hayes, T.L. (2002). Business-unit-level relationship between employee satisfaction, employee engagement, and business outcomes: A Meta-analysis. Journal of Applied Psychology, 87(2), 268-279.

Higgins, M.C. (2000). The more, the merrier? Multiple developmental relationships and work satisfaction. Journal of Management Development, 19(4), 277-296.

Irving, E.S., Moore, W.D. \& Hamilton, R.J. (2003). Mentoring for high ability school students. Education and Training, 45(2), 100-109.

Johnson, N.B. \& Scandura, T.A. (1994). The effect of mentorship and sex-role style on male-female earnings. Industrial Relations, 33, 263-374.

Juchnowicz, M. (2010a). Zarzadzanie przez zaangażowanie. Warszawa: Polskie Wydawnictwo Ekonomiczne.

Juchnowicz, M. (2010b). Zarządzanie kapitałem ludzkim a poziom zaangażowania pracowników. Zarzadzanie Zasobami Ludzkimi, 3-4, 57-58.

Klasen, N. \& Clutterbuck, D. (2002). Implementing Mentoring Schemes. A Practical Guide to Successful Programs. London \& New York: Routledge Taylor \& Francis Group.

Koberg, C.S., Boss, R.W., Chappell, D. \& Ringer, R.C. (1994). Correlates and consequences of protégé mentoring in a large hospital. Group and Organization Management, 19, 219-239.

Kram, K.E. (1983). Phases on the mentor relationship. Academy of Management Journal, 26, 608-625. 
Kruse, K. (2012). What is employee engagement. Forbes. http://www.forbes. com/ sites/kevinkruse/2012/06/22/employee-engagement-what-and-why/ (access: 21.03.2017).

Luthans, F., Norman, S.M., Avolio, B.J. \& Avey, J.B. (2008). The mediating role of psychological capital in the supportive organizational climate: employee performance relationship. Journal of Organizational Behavior, 29, 219-238.

Maslach, C., Schaufeli W. B. \& Leiter, M.B. (2001). Job burnout. Annual Review of Psychology, 52.

Megginson, D. \& Stokes, P. (2004). Mentoring for export success. In: J. Stewart \& G. Beaver (eds.), HRM in Small Organizations: Research and Practice. Abingdon: Routledge, 265-285.

Meyer, J.P. \& Smith A.C. (2000). HRM practice and organizational commitment. test of mediation model. Canadian Journal od Administrative Sciences, 17.

Parsloe, E. (2000). Coaching i mentoring. Warszawa: Petit.

Ragins, B.R. (2002). Understanding diversified mentoring relationships: definitions, challenges, and strategies. In D. Clutterbuck \& B.R. Ragins (eds.), Mentoring and Diversity: An International Perspective. Oxford: Butterworth Heinemann, 23-25.

Ragins, B.R. \& Cotton, J.L. (1999). Mentor functions and outcomes: A comparison of men and women in formal and informal mentoring relationships. Journal of Applied Psychology, 84(4), 529-550.

Ragins, B.R. \& McFarlin, D.B. (1990). Perceptions of mentor roles in cross-gender mentoring relationships. Journal of Vocational Behavior, 37, 321-339.

Robinson, D., Perryman, S. \& Hayday, S. (2004). The Drivers of Employee Engagement Report. Institute for Employment Studies. http://www.employment-studies. co.uk/pubs/summary.php?id=408 (access: 25.05.2016).

Roche, G.R. (1979). Much ado about mentors. Harvard Business Review, 57(1), 17-28.

Russell, J.A. (2003). Core affect and the psychological construction of emotion. Psychological Review, 110.

Saks, A.M. (2006). Antecedents and consequences of employee engagement. Journal of Managerial Psychology, 21(7).

Salanova, M., Agut, S. \& Peiró, J.M. (2005). Linking organizational resources and work engagement to employee performance and customer loyalty: The Mediation of Service Climate. Journal of Applied Psychology, 90, 1217-1227.

Scandura, T.A. (1992). Mentorship and career mobility: An empirical investigation. Journal of Organizational Behavior, 13, 169-174.

Schaufeli, W.B. \& Bakker, A.B. (2003). UWES Utrecht work engagement scale: Preliminary manual. Version 1, November. Occupational Health Psychology Unit, Utrecht University. 
Schaufeli, W.B. \& Bakker, A.B. (2004). Job demands, job resources and their relationship with burnout and engagement: a multi-sample study. Journal of Organizational Behavior, 25, 293-315.

Schaufeli, W.B. \& Van Rhenen, W. (2006), Over de rol van positieve en negatieve emoties bij het welbevinden van managers: Een studie met de Job-related Affective Well-being Scale (JAWS) (About the role of positive and negative emotions in managers' well-being: A study using the Job-related Affective Well-being Scale (JAWS)). Gedrag \& Organisatie, 19, 323-244.

Schaufeli, W.B., Bakker, A.B. \& Van Rhenen, W. (2008). How Changes in Job Demands and Resources Predict Burnout, Work Engagement, and Sickness Absenteeism. Manuscript submitted for publication.

Schaufeli, W.B., Salanova, M., Gonzalez-Roma, V. \& Bakker, A.B. (2002). The measurement of engagement and burnout and: a confirmative analytic approach. Journal of Happiness Studies, 3, 71-92.

Shirom, A. (2011). Vigor as a Positive Affect at Work: Conceptualizing Vigor, Its Relations with Related Constructs, and its Antecedents and Consequences. Review of General Psychology, 15.

Smythe J. (2009). CEO - dyrektor do spraw zaangażowania. Kraków: a Wolters Kluwer business.

Sy, T., Cote, S. \& Saavedra, R. (2005). The contagious leader: impact of leader's affect on group member affect and group processes. Journal of Applied Psychology, 90, 295-305.

Turban, D.B. \& Dougherty, T.W. (1994). Role of protégé personality in receipt of mentoring and career success. Academy of Management Journal, 37, 688-702.

Van Knippenberg, D. (2000). Work motivation and performance: A social identity perspective. Applied Psychology, 49(3), 357-371.

Westman, M. (2001). Stress and strain crossover. Human Relations, 54, 557-591.

Wilson, J.A. \& Elman, N.S. (1990). Organizational benefits of mentoring. Academy of Management Executive, 4, 88-94.

Zey, M.G. (1988). A mentor for all reasons. Personal Journal, 67(1), 46-51. 


\title{
ZNACZENIE MENTORINGU DLA ZAANGAŻOWANIA PRACOWNIKÓW W PRACĘ - NA PODSTAWIE BADAŃ PRACOWNIKÓW PRZEDSIĘBIORSTW W POLSCE
}

\begin{abstract}
Abstrakt
Tło badań. Na sukces przedsiębiorstwa wpływają uwarunkowania wewnątrzorganizacyjne, jak i otoczenie zewnętrzne, które współcześnie jest bardzo turbulentne i wymagające. Niewątpliwie jednak kluczową rolę w osiaganiu przez firmę sukcesów odgrywa kapitał ludzki, a więc pracownicy z określonymi emocjami, postawami i zachowaniami, w których przejawia się zaangażowanie pracowników. Badania wskazuja, że jednym ze skutecznych narzędzi wspierania pracowników jest mentoring. Wpływa on nie tylko na szeroko pojęty rozwój samych pracowników, ale także na rozwój całej organizacji. Poprzez oddziaływanie na postawy pracowników, ich emocje, zachowania, wpływa na ich zaangażowanie, sprzyjając sukcesowi przedsiębiorstwa.
\end{abstract}

Cel badań. Celem artykułu jest zbadanie zależności pomiędzy korzystaniem przez pracowników z mentoringu w firmie, a ich zaangażowaniem w pracę

Metodologia. Przeprowadzone zostało badanie ilościowe na dobranej celowo próbie 1010 pracowników przedsiębiorstw funkcjonujących w Polsce, którzy brali udział w procesie mentoringowym w swojej firmie. Kryterium udziału w badaniu było ukończenie przez pracownika procesu mentoringowego. Stosowana technika badawczą była technika ankietowa. Zastosowana metoda pozwoliła autorce dzięki standaryzacji pytań, uzyskać zbiorcze i porównywalne ze sobą dane.

Na potrzeby prowadzonych badań oparto się na często wykorzystywanej koncepcji zaangażowania w pracę autorstwa Schaufeli. W badaniu wykorzystano kwestionariusz Praca i Samopoczucie UWES - Utrecht Work Engagement Scale.

Kluczowe wnioski. Udział pracowników w procesie mentoringu wpływa na ich zaangażowanie w pracę. Jak wynika $\mathrm{z}$ analizy statystycznej uzyskanych wyników badania, zaangażowanie pracowników w pracę jest dodatnio skorelowane z korzystaniem przez nich z procesów mentoringowych w przedsiębiorstwie.

Słowa kluczowe: mentoring, zaangażowanie w pracę, pracownicy. 